\title{
Production of Reinforced Polyester Composite from Okra Fibre and Sawdust
}

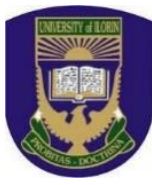 \\ T. K. Bello ${ }^{1 *}$, M. O. Oladipo ${ }^{1}$, A. Idris ${ }^{1}$, F. B. Beka ${ }^{2}$, U. P. Unachukwu ${ }^{1}$, A. Bukar ${ }^{1}$ \\ ${ }^{1}$ Department of Chemical Engineering, Ahmadu Bello University, Samaru Zaria, Kaduna State, Nigeria. \\ ${ }^{2}$ Mouka Limited Kaduna, Kakuri Industrial Area, Kaduna State, Nigeria.
}

ABSTRACT: This research presents properties of okra and sawdust reinforced polyester composite. The compatibility of the simple woven okra and sawdust with polyester was enhanced with stearic acid treatment. FTIR analysis confirmed decrease in hydrophilicity of the fibre and dust. Six composite samples; pure polyester, sawdust reinforced polyester composite, okra reinforced polyester composite, $10 \%$ sawdust in okra fibre reinforced composite, $20 \%$ sawdust in okra fibre reinforced composite and 30\% sawdust in okra fibre reinforced composites were fabricated and characterized. The morphological analysis showed that the homogeneity of polyester in the samples reduces with increase in sawdust filler (10-30 wt\%). Water absorption was highest (1.6\%) in 30\% sawdust in okra. The densities of all the composites were between $3.5-4.5 \mathrm{~kg} / \mathrm{m}^{3}$. The sawdust reinforced composite recorded low impact energy of $0.25 \mathrm{~J}$ while the woven okra fibre reinforced polyester recorded the highest impact energy of $9.9 \mathrm{~J}$. Hardness property reduced as the biomass content increased. Unreinforced polyester recorded the highest average elongation of $25 \%$ $(1400 \mu \mathrm{m})$ and reduced elongation as filler increased. The storage modulus was highest for unreinforced composite at $40{ }^{\circ} \mathrm{C}$ but as the temperature reached $81{ }^{\circ} \mathrm{C}$ the storage modulus of unreinforced polyester dropped lower than the sawdust composite. The damping factor (1.41) was highest for $20 \mathrm{wt} \%$ sawdust/okra polyester composite. This research concludes that sawdust and okra are suitable for lightweight and energy damping materials in automobile applications.

KEYWORDS: Weight loss, activation parameters, adsorption, optimization, stainless steel, castor leaf.

\section{INTRODUCTION}

Natural/green fibre reinforced composites have been receiving tremendous attention in recent times. This is especially in areas of material science, engineering researches and applications. Natural fibres such as wool, wood, okra, sisal, jute etc. are light weight, low cost, abundant in nature and renewable when compared to synthetic materials (Gurunathan et al., 2015; Horta et al., 2017). The biodegradability nature of these materials favours sustainable environment and is responsible for the growing interests. (Ahmad et al., 2018; Thyavihalli et al., 2019). Their properties have attracted scientists and engineers to consider them for automobile, construction, upholstery applications (Mohammed et al., 2015; Li et al., 2020; Merzoug et al., 2020). Natural fibres have drawbacks as, they are not readily compatible with synthetic matrices (Gurunathan et al., 2015; Hamidon et al., 2019). Therefore, the need for fibre modification to improve the compatibility (Asim et al., 2020).

Okra which is a vegetable crop that belongs to the genus Abelmoschus, family Malvaceae has two main species: Abelmoschus esculentus (L.) Moench and Abelmoschus caillei (A. Chev.) Stevels (Letebrhan et al., 2020). Abelmoschus esculentus (L.) Moench is mostly cultivated in western Nigeria (Ijoyah and Dzer, 2012) where the stem is rarely consumed.

*Corresponding author: tkbello@abu.edu.ng
This can be extracted as a natural fibre for reinforced composite application. Effective utilization of okra is necessary to curb wastage being experienced during peak season (Ngbede et al., 2017). Wood dust or sawdust on the other hand is obtained from the wood industry as waste. Wood like mahogany (Afzelia africana) is significantly utilized in woodwork industry in Nigeria causing a substantial sawdust build-up (Okonkwo et al., 2016). These build-ups when improperly disposed find their ways in open areas, drainage systems and water bodies thereby causing floods, land, water and air pollution. Nigeria's 1.8 million tons annual sawdust production if not properly utilized will have negative impact on the terrestrial and aquatic ecosystems (Owoyemi et al., 2016). Sawdust utilization in fibre reinforcement reduce environment pollution caused by incineration, increased local economic growth and create employment (Oluoti et al., 2014; Ogunwusi et al., 2014)

Morphological properties of fibres greatly influence the performance of composites (Nayak et al., 2017). Natural fibres are hydrophilic while synthetic matrices are hydrophobic. Water repellency, lamination adhesiveness, wettability and biocompatible processes are greatly affected by their surface morphology of the reinforcing fibres (Marcovich et al., 1996; Popelka et al., 2020). The hydrophilicity can however be modified by physical or 
chemical processes. These modifications will promote interfacial adhesion between the modified fibre and the matrix (Wassamon et al., 2013). A good modification enhances stress transfer between the matrix and the fibre thereby improving the overall physical and/or mechanical properties (ValadezGonzalez et al., 1999; Thitithanasarn et al., 2012). The mechanical properties reflect the motion state inside the composites and are important to the efficient use of the fibrereinforced polymer composites (Zhang et al., 2017). Hybridized composites largely depend on fibre length, fibre strength and orientation for high mechanical strength, noise absorption, abrasion etc (Misganew et al., 2020; Unterweger et al., 2014). These properties are some of the capabilities that natural fibre reinforced composites are offering the current growing automobile and building industries (Ahmad et al., 2014).

This work focuses on the morphology, physical and mechanical properties studies of natural fibre (of okra and sawdust) reinforced polyester composite for engineering applications.

\section{MATERIALS AND METHODS}

A. Materials

Okra fibre and sawdust were sourced from Dogarawa Garden and Sabon gari market, Samara Zaria in Nigeria, respectively. Stearic acid (Alderich reagent grade), methylethylketone peroxide catalyst (Alderich analytical standard), cobalt nephthenate accelerator (Alderich laboratory chemical), and general purpose polyester resin (standard grade) were bought from Haddis International, Samaru Zaria.

\section{B. Methods}

1) Extraction of okra fibre and sawdust particle

The stem of the okra plant was soaked in water for 7 days to soften for fibre extraction. The water absorbed in the stem swells in inner cells and weakens the outer layers. The fibre was then extracted manually by beating the softened stems and then scraping the pulp away with a knife as described by Hulle et al., (2015). The sawdust was grounded using Kere Soesterberg milling machine then sieved with a sieve of mesh size $125 \mu \mathrm{m}$. The images of the okra fibre and sawdust are shown in Figure 1. The sample was thereafter stored in a desiccator before use.
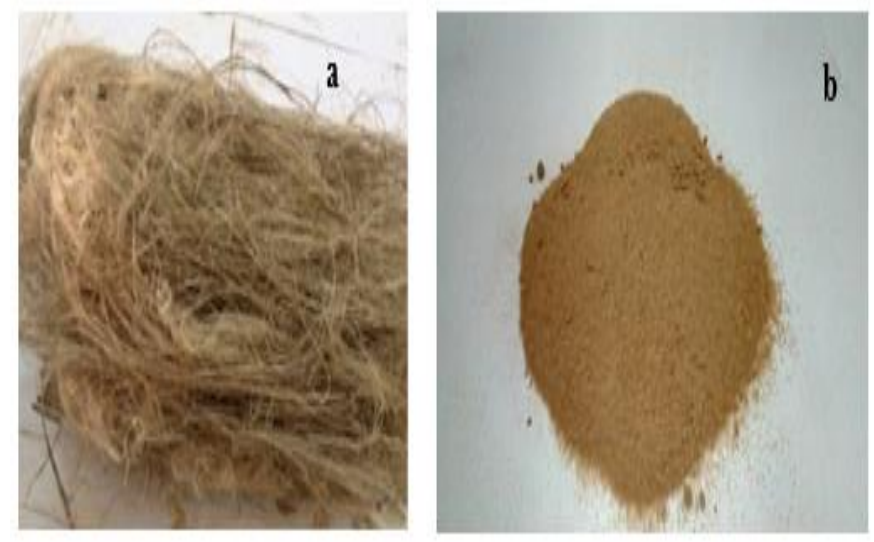

Figure 1: (a) Extracted okra fibre; (b) Grounded sawdust.

\section{2) Treatment of okra fiber and sawdust}

$40 \mathrm{~g}$ of the dried castor leave powder was transferred into $10 \mathrm{~g}$ of stearic was dissolved in $13 \mathrm{mls}$ of ethanol, then added to a litres distilled water as described by La Mantia and Morreale (2011). The extracted Okra fibre of mass $300 \mathrm{~g}$ was then soaked into the solution and stirred for 24 hours with the aid of Hangzhou HC-100 thermo shaker. The fibre was then washed thoroughly with water and dried. The same procedure was repeated for sawdust treatment.

\section{3) Weaving the treated okra fiber}

The okra fibre was woven using the plain weave method as shown in Figure 2. The woven fibre was of $6 \times 6$ inches dimension based on the size of the mold.
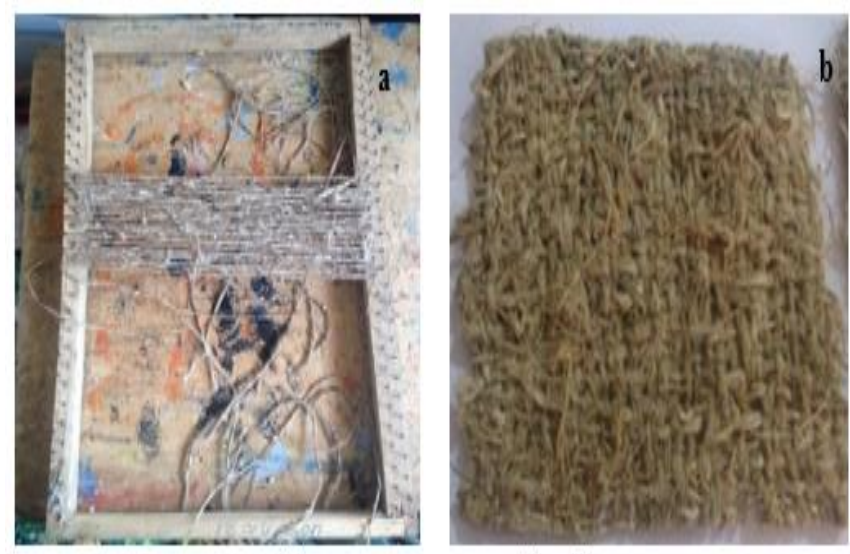

Figure 2: (a) Weaving machine (b) P̈lain woven Okra fibre.

\section{4) Preparation of the composite}

The mould was thoroughly cleaned and waxed to aid removal of the composite using Isa et al. (2016) method. The woven fibre ( $6 \times 6$ inch) was placed in the cavity of the mould. For a basis of $100 \mathrm{~g}$ sample, $100 \mathrm{~g}$ of polyester resin was measured into $250 \mathrm{ml}$ beaker, $2 \mathrm{~g}$ of catalyst (methyl ethyl ketone peroxide) was added and stirred for 1 minute. $2 \mathrm{~g}$ of cobalt naphthenate was then added and stirred. The mixture was transferred to the mold containing the woven okra fibre and allowed to cure for 60 minutes, after which the cured composite was carefully removed and dried $\left(60{ }^{\circ} \mathrm{C}\right)$ in an oven. Six samples described in Table 1 and shown in Figure 3 were produced and taken for analysis.

Table 1: Constituents and composition of the fabricated composite samples.

\begin{tabular}{|c|c|c|c|}
\hline Sample & $\begin{array}{c}\text { Okra } \\
\text { fibre (g) }\end{array}$ & $\begin{array}{l}\text { Sawdust } \\
(\mathrm{g})\end{array}$ & $\begin{array}{l}\text { Polyester resin } \\
\text { (g) }\end{array}$ \\
\hline $\begin{array}{l}\text { (a) Pure Polyester } \\
\text { resin }\end{array}$ & - & - & 200 \\
\hline $\begin{array}{l}\text { (b) Sawdust } \\
\text { reinforced } \\
\text { polyester }\end{array}$ & - & 20 & 180 \\
\hline $\begin{array}{l}\text { (c) Okra mat } \\
\text { reinforced } \\
\text { polyester }\end{array}$ & 40 & - & 160 \\
\hline $\begin{array}{l}\text { (d) } 10 \% \text { Sawdust }+ \\
\text { Okra mat }\end{array}$ & 34.4 & 3.82 & 161.78 \\
\hline $\begin{array}{l}\text { (e) } 20 \% \text { Sawdust + } \\
\text { Okra mat }\end{array}$ & 40 & 10 & 150 \\
\hline $\begin{array}{l}\text { (f) } 30 \% \text { Sawdust + } \\
\text { Okra mat }\end{array}$ & 44 & 20 & 136 \\
\hline
\end{tabular}



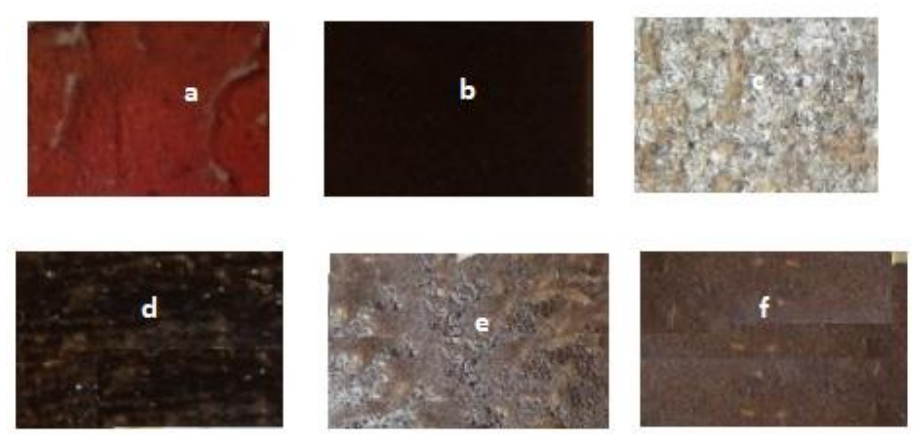

Figure 3: Composites formed from okra and sawdust reinforced in polyester resin: (a) pure polyester resin; (b) Sawdust reinforced polyester; (c) Okra mat reinforced polyester; (d) $10 \%$ Sawdust + Okra mat; (e) $20 \%$ Sawdust + Okra mat; (f) $30 \%$ Sawdust + Okra

\section{5) Tests and analysis}

a) Spectroscopy and Morphological testing of treated fibres: Fourier transform infrared spectrometry using (FTIR-ART machine (Happ-Genzel, Agilent Technologies, USA) and Phenom TM Prox scanning electron microscopy (SEM) were employed in carrying out functional group analysis and morphology of the composites respectively.

b) Mechanical testing: The mechanical tests performed were the impact, hardness, water absorption and tensile strength tests.

c) Impact testing: Charpy impact test machine with serial number $412-07-15269 \mathrm{C}$ was used with a capacity of $15 \mathrm{~J}$ for composites following ASTM E23 standard method.

d) Hardness test: The Rockwell hardness test of machine type 6187.5B with serial number 053158 was used. The Scale F (Soft materials) with the 1/16-inch ball was used according to the ASTM D2240.

e) Water absorption test: The 24-hour procedure according to (ASTM D570) was used and the samples were weighed before and after immersion. Water absorption is calculated in percentage using Eq. 1, where $\mathrm{w}_{\mathrm{o}}$ is the initial weight and $\mathrm{w}$ is the final weight.

Water absorption $(\%)=\frac{w-w_{o}}{w_{o}} \times 100$

f) Tensile test: The composite was shaped into a threedumbbell shape according to ASTM D638. The Monsanto tensometer type 'w' with serial number 9875 was used. The samples were fixed between the teeth of the machine and pulling continuously until rupture occured. The graph was used to determine the young modulus, percentage elongation, strain and maximum tensile strength.

g) Dynamic mechanical analysis: Each of the samples of the pure polyester and composites were cut into a rectangular shape of $40 \mathrm{~mm} \times 10 \mathrm{~mm} \times 5 \mathrm{~mm}$. Netzsch 242E analyser was operated at 3-point bending mode, set at $10 \mathrm{~K} / \mathrm{min}$ and $1 \mathrm{~Hz}$ frequency. The storage, loss modulus, $\tan \delta$ and elongation were however determined using the Netzsch Proteous software.

\section{RESULTS AND DISCUSSION}

A. Fourier Transform Infrared Spectroscopy of the Fabricated Okra-Sawdust Reinforced Composite

Figure 4(a-b) shows the FTIR of the (a) untreated and treated okra fibre and (b) untreated and treated sawdust. The absorption band observed in $3280.15 \mathrm{~cm}^{-1}$ in the okra fibre and $3300 \mathrm{~cm}^{-1}$ in sawdust are characteristic bands for the hydroxyl groups from complex vibrational stretching. The free inter and intra molecular bound hydroxyl groups are responsible for the hydrophilic nature of natural fibres. It also makes them incompatible with hydrophobic matrices such as polyester. After the stearic acid treatment, the intensity of the peaks was greatly reduced implying the removal of some bonded $\mathrm{O}-\mathrm{H}$ group. This hydroxyl group removal is good for fibre matrix compatibility (Wassamon et al., 2013). The peak $2922.2 \mathrm{~cm}^{-1}$ characterized $\mathrm{C}-\mathrm{H}$ stretch in methyl and methylene group was not affected by the treatment.

The carbonyl $\mathrm{C}=\mathrm{O}$ stretch $(1720-1740) \mathrm{cm}^{-1}$ as in unconjugated ketone, carbonyl and ester groups in the untreated fibre represents the non-cellulosic components (pectin, lignin and hemicelluloses) which reduced significantly in treated fibres. There was also reduction in absorbed water $(\mathrm{OH})$ shown at peak $(1630-1650) \mathrm{cm}^{-1}$. A sharp drop in peak at $(1020-1050) \mathrm{cm}^{-1}$ corresponding to symmetric $\mathrm{C}-\mathrm{OH}$ stretching of lignin was observed. The lignin reduction is vital in natural fibre-synthetic matrix compatibility. The wavenumber $\left(1420 \mathrm{~cm}^{-1}\right)$ indicating aromatic skeleton vibrations combined with $\mathrm{C}-\mathrm{H}$ in-plane
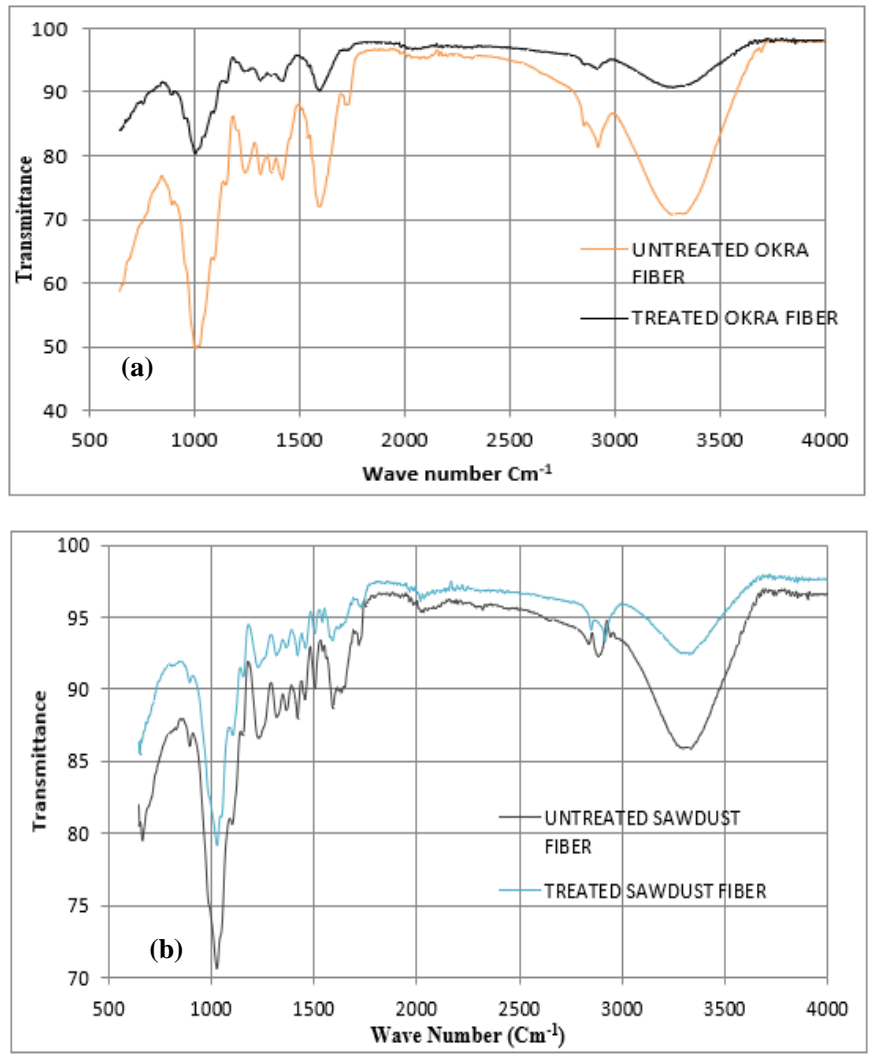

Figure 4: FTIR spectra of untreated and treated (a) okra and (b) sawdust. 
deformations $\left(\mathrm{CH}_{2}\right.$ bending of cellulose $)$ was still present in the treated fibre. The peak at $1319.5 \mathrm{~cm}^{-1}$ signifies the presence of $\mathrm{C}-\mathrm{O}$ group of the aromatic ring in polysaccharides. At $1367.9 \mathrm{~cm}^{-1}$, there is bending vibration of $\mathrm{C}-\mathrm{H}$ of the aromatic ring in polysaccharides. The $1244.95 \mathrm{~cm}^{-}$ ${ }^{1}$ band in the untreated okra fibre (Figure $4 \mathrm{a}$ ) represents the $\mathrm{C}=\mathrm{O}$ stretching vibration of the acetyl group in lignin which reduced in the treated fibre.

\section{B. SEM Analysis for the Produced Composites}

The SEM micrographs in Figure 5 show the micro fibres and sawdust particles as highlighted. The micrographs revealed the homogeneity of the pure polyester composites (a) and dispersions of sawdust particles in the composites containing sawdust (samples b, d, e and f). The sawdust gave a better dispersion compared to the okra fibre in the matrix implying sawdust will absorb more water when exposed and also have higher mechanical properties. It can also be deduced that dispersion and homogeneity of polyester in the samples reduces with increase in filler sawdust as seen in the $10 \%$, $20 \%, 30 \%$ sawdust and okra fibre composites.
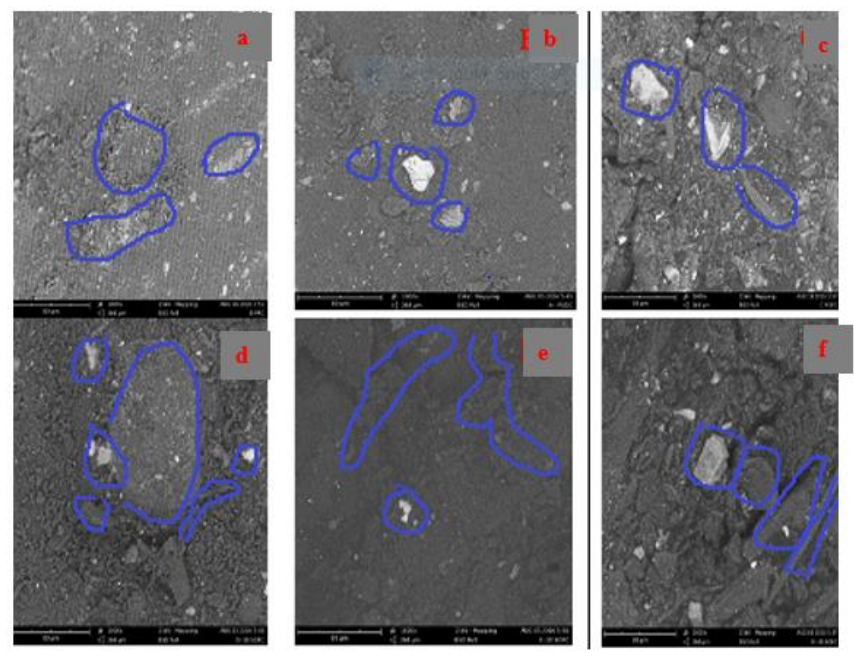

Figure 5: SEM analysis of the fabricated composite samples: (a) pure polyester resin; (b) Sawdust reinforced polyester; (c) Okra mat reinforced polyester; (d) $10 \%$ Sawdust + Okra mat; (e) $20 \%$ Sawdust + Okra mat; (f) $30 \%$ Sawdust + Okra mat.

\section{Physical Properties of the Composite Samples}

The ability to absorb water increased from sample A to F as shown in Figures 6-7. Sample A (unreinforced polyester) had the least water absorption of $0.09 \%$, this is as a result of the hydrophobicity of pure polyester resin.

The hydrophobicity property of the polyester decreased with increase in natural fibre added to it, even though the fibres were treated. The treated natural fibres still possess some degree of hydrophilicity although reduced as shown in the FTIR results presented (Negawo et al., 2018; Obogai et al., 2020).

The composite with okra and 30\% sawdust (Sample F) recorded the highest water absorption capacity of $1.6 \%$. The densities of all the composites were between $3.5-4.5 \mathrm{~kg} / \mathrm{m}^{3}$. For the hybrid composites (samples D - F), D recorded the highest density of $3.82 \mathrm{~kg} / \mathrm{m}^{3}$.

\section{Mechanical Properties of the Composites}

The mechanical properties of the composites were analysed based on the impact energy, hardness, elongation and Young's modulus as shown in Figures 8-11. The okra mat reinforced composite recorded the highest impact energy of 9.9 J while sawdust composite had the least impact energy of $0.25 \mathrm{~J}$. Addition of $10 \%$ by weight sawdust to okra mat reduced its impact to $4.35 \mathrm{~J}$ which is about the same energy of unreinforced polyester composite. Implying that biomass even though light weight at certain composition and orientation can be tailored to have same or even better property of the unreinforced polyester (Obogai et al., 2020).

Hardness and percentage elongation property reduced with filler content implying reduced ductility nature of the material as filler content increased (Sanjay et al., 2018; Siakeng et al., 2018) with unreinforced polyester recording the highest average elongation of $25 \%$.

The Young's modulus is tenacity, rigidity and resistance of a material to deformation; otherwise known as modulus of elasticity (Silva-Guzmán et al., 2018). It is. Increase in sawdust composition led to an increase in Young's modulus of the woven okra mat (samples C-F) until it attained a maximum Young's modulus value of $120 \mathrm{~N} / \mathrm{mm}^{2}$. It then further dropped to $58 \mathrm{~N} / \mathrm{mm}^{2}$ at $30 \%$ sawdust on okra fibre reinforced polyester. This increase in property can be attributed to a proper adhesion, compatibility and interaction between constituent okra and sawdust in the polyester matrix (Ramadevi et al., 2014; Horta et al., 2017).

\section{E. Dynamic Mechanical Analysis (DMA) of the Produced Composites}

The dynamic mechanical analysis as presented in Figures (12-15) showed storage modulus decreased with temperature. This is as expected due to increased molecular mobility of polymer chains (Mandal and Alam, 2012; Sethuraman et al., 2020). The Young's modulus decrease is significant at the glass transition temperature $\left(>60^{\circ} \mathrm{C}\right)$ where there were several orders of magnitude drop (Paiva and Frollini, 2006; Poletto, 2017; Doddi et al., 2019). The unreinforced composite recorded the highest storage modulus followed by sawdust reinforced polyester (b). This trend in storage modulus is similar to that of the Young modulus (Figure 11) i.e the storage modulus of unreinforced sample (a) is $2800 \mathrm{MPa}$ while sample with $10 \%$ sawdust (b) is $2100 \mathrm{MPa}$. This difference however reduces as the temperature increased until the temperature reaches $80{ }^{\circ} \mathrm{C}$ where the storage modulus of the two composite coincides. At $81^{\circ} \mathrm{C}$, the sawdust reinforced composite storage modulus exceeds that of the unreinforced polyester.

This implies that if the material is required at higher temperature environment and at modulus not exceeding 500 $\mathrm{MPa}$, the sawdust reinforced composites will perform better. The loss modulus which is the maximum energy given out 
during deformation exhibited similar trend to the storage modulus. The unreinforced material recorded the highest loss modulus followed by the sawdust reinforced composite. This behavior of storage and loss will be better appreciated in the damping factor which is a ratio of loss modulus to storage modulus. It is observed that the loss modulus initially increased with temperature to about $60-75^{\circ} \mathrm{C}$ before dropping (Asim et al., 2019; Krishnasamy et al., 2019).

The peak of the damping property is usually linked to the glass transition property of the material (Sethuraman et al., 2020). While all the peak of Tan $\delta$ occurred around $100{ }^{\circ} \mathrm{C}$,

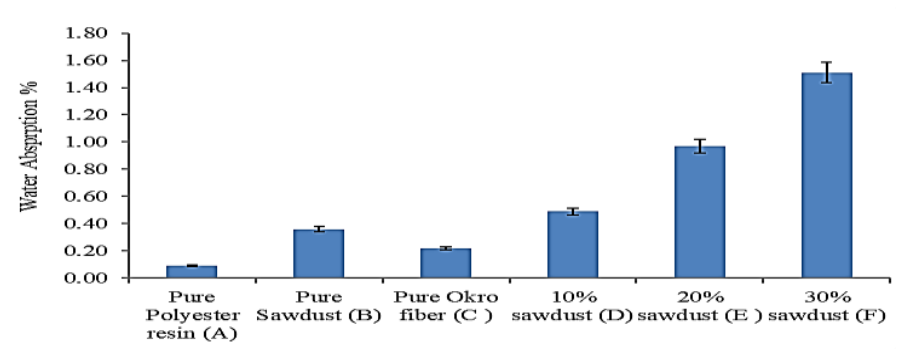

Figure 6: Water absorption property of the composites.

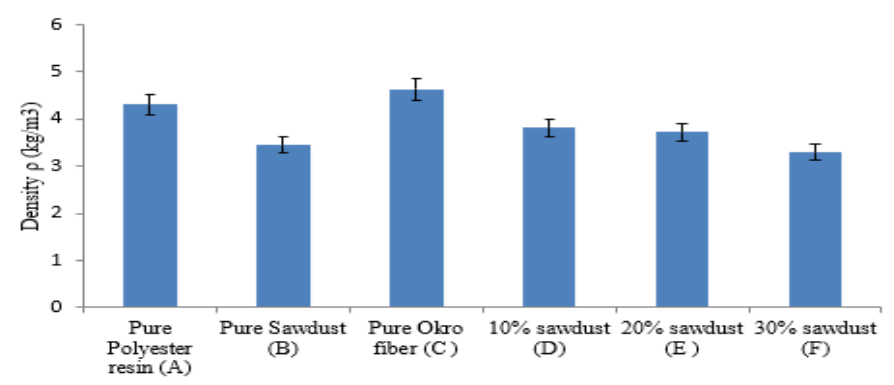

Figure 7: Densities of the composite samples.

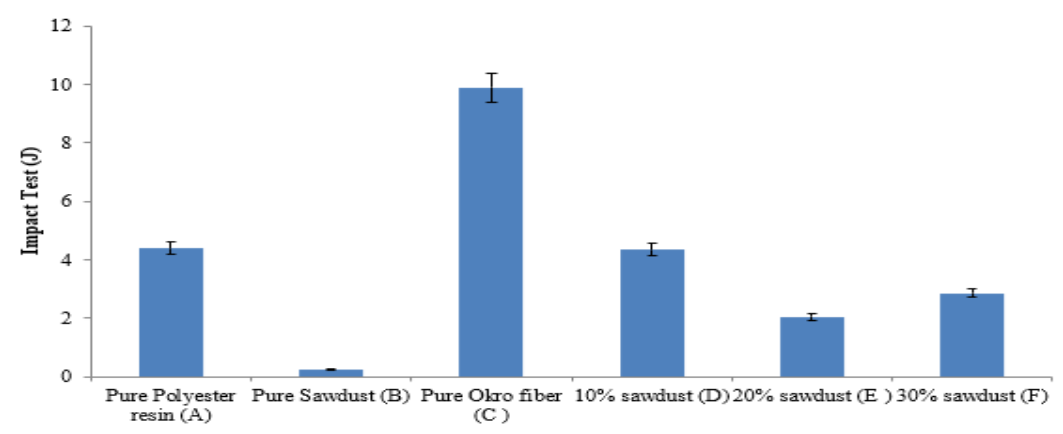

Figure 8: Impact energy of the composites. the glass transition temperature $(\mathrm{Tg})$ can be said to be at 100 ${ }^{\circ} \mathrm{C}$. There is no significant difference in T_g as the reinforced material increased. The damping factor (1.41) was highest for $20 \mathrm{wt} \%$ sawdust /okra polyester which implies that sawdust and okra can help to increase damping property of a material and are candidate material for material damping and automobile industry (Ahmad et al., 2014, Poletto, 2017; Chaudhary et al., 2018). The elongation measures the quantity and quality of the ductility nature of a material. A decrease in elongation was observed for filled composite indicating that the fillers reduced the elasticity property of the material.

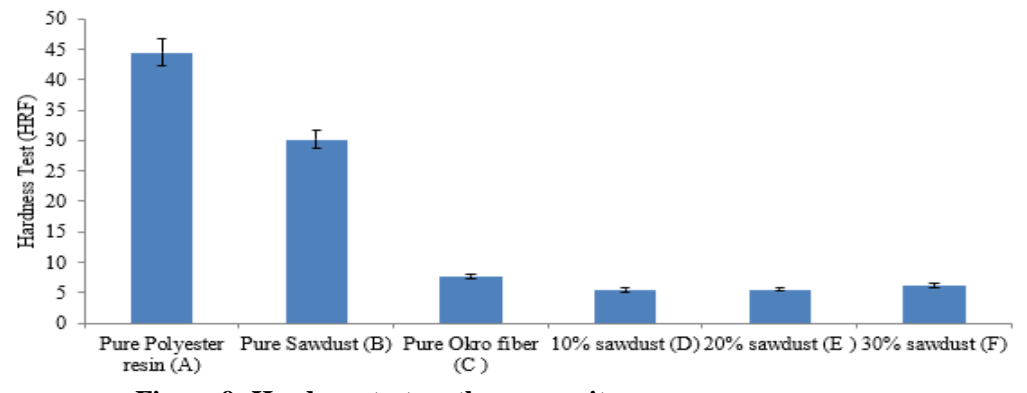

Figure 9: Hardness test on the composites.

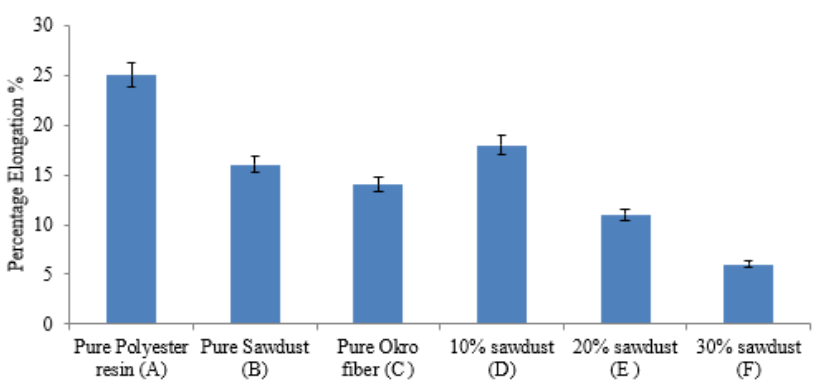

Figure 10: Percentage elongation of the composites.

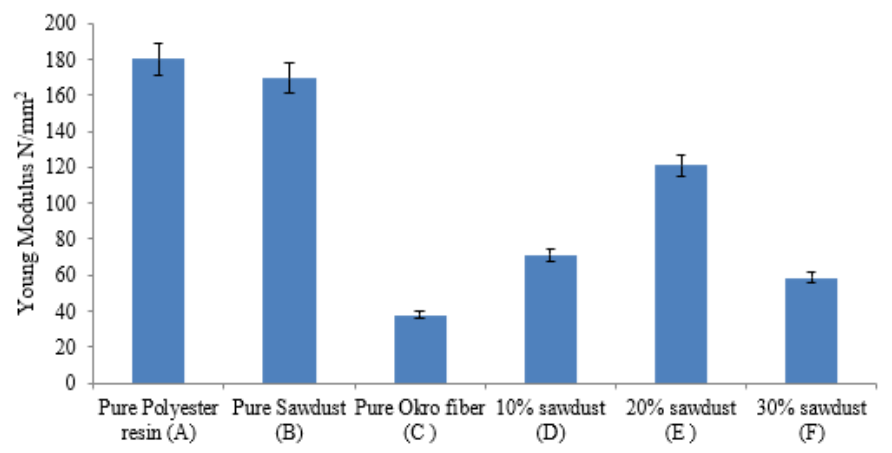

Figure 11: Young Modulus of the composites.

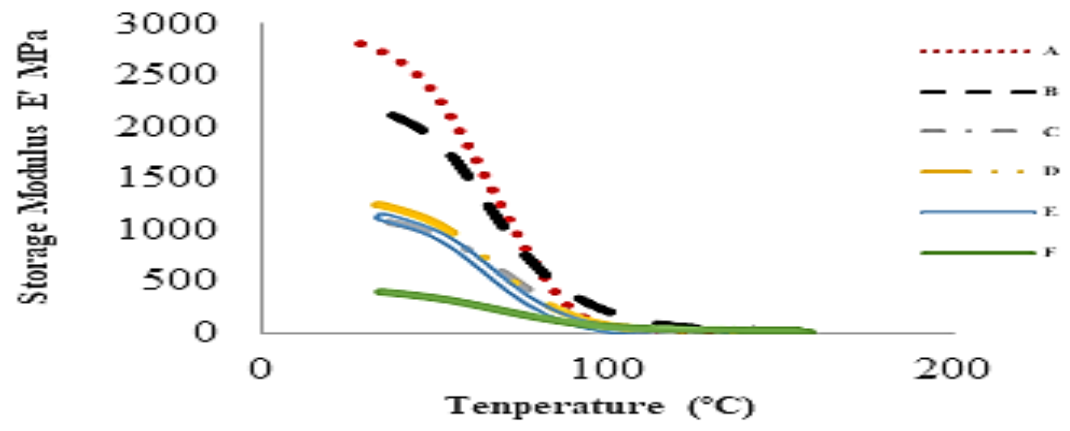

Figure 12: Effect of temperature on the storage modulus of pure polyester and the composites. 


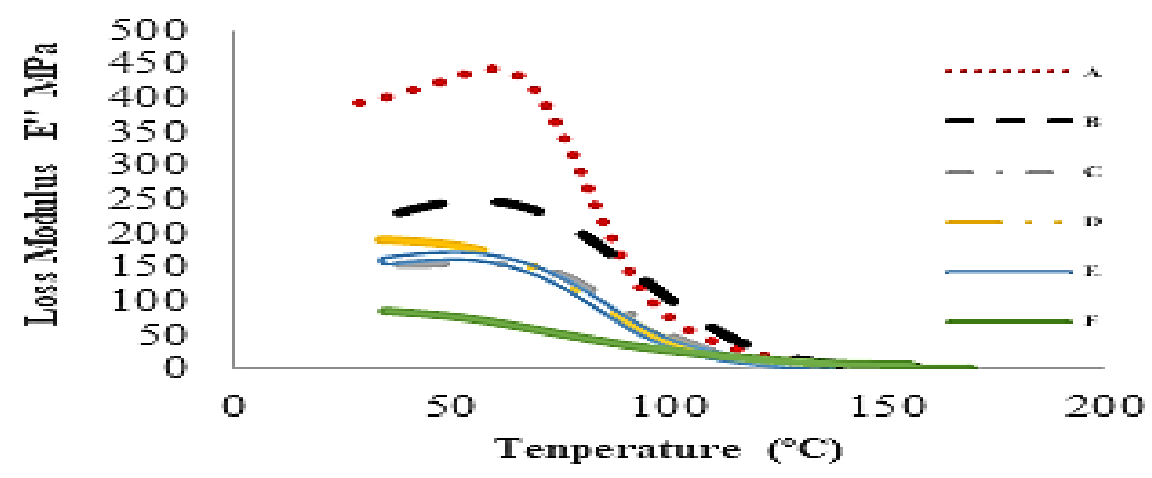

Figure 13: Effect of temperature on the loss modulus of pure polyester and the composites.

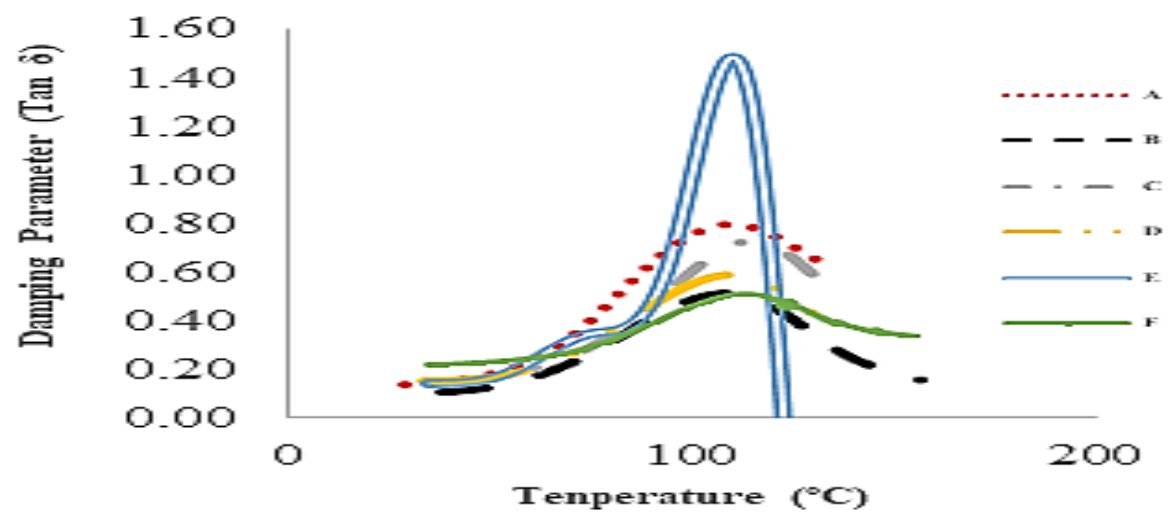

Figure 14: Effect of temperature on the Tan $\delta$ of pure polyester and the composites.

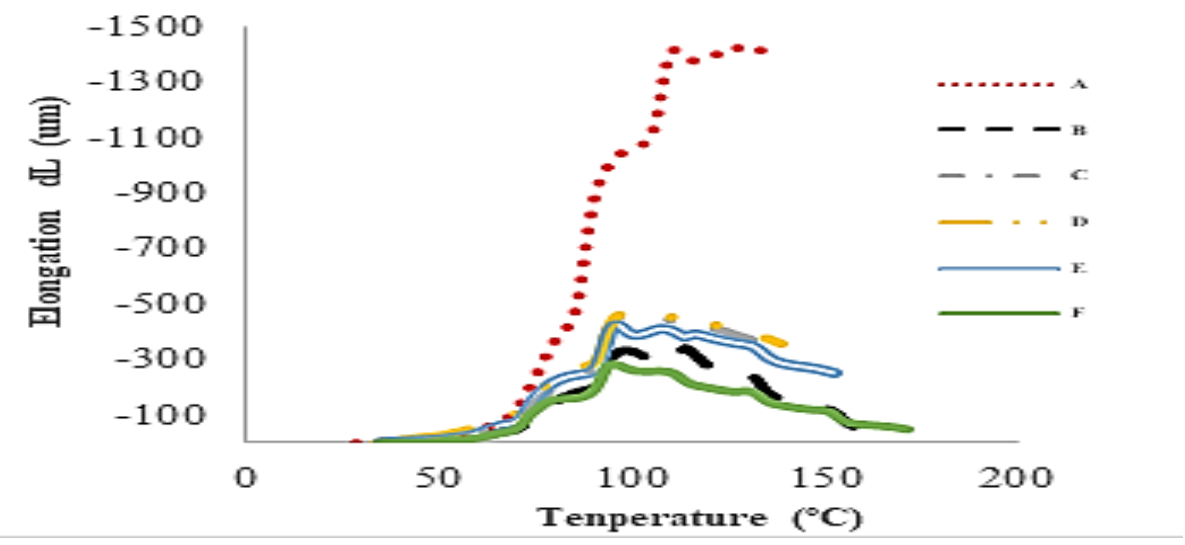

Figure 15: Effect of temperature on the elongation parameter of pure polyester and the composites.

\section{CONCLUSION}

The use of stearic acid in fibre treatment reduced the hydrophilicity of the material thereby improving the fibre/matrix interaction. The physical properties of the composites showed that the composite with okra and $30 \%$ sawdust (Sample F) recorded the highest water absorption capacity of $1.6 \%$, also the densities of all the composites ranges between $3.5-4.5 \mathrm{~kg} / \mathrm{m}^{3}$. The okra mat reinforced composite recorded the highest impact energy of $9.9 \mathrm{~J}$ than the unreinforced (control) material. The hardness of the reinforced material showed a decline as the biomass content increased in the composite. The unreinforced polyester recorded highest average elongation of $25 \%$. This property 
dropped with increase in okra and sawdust in the composite. In the hybrid composite, sawdust content improved the Young's modulus of the woven okra mat (samples C-F). Even though the unreinforced composite recorded the highest storage modulus at $40{ }^{\circ} \mathrm{C}$, the sawdust reinforced composite recorded the highest at $81{ }^{\circ} \mathrm{C}$ and beyond prompting the use of reinforced composites at higher temperatures.

\section{REFERENCES}

Ahmad, F.; H. S. Choi and M. K. Park (2014). A Review: Natural Fiber Composites Selection in View of Mechanical, Light Weight, and Economic Properties. Macromolecular Materials and Engineering, 300 (1): 10-24

Ahmad, M. A. A.; M. S. Abdul Majid, M. J. M. Ridzuan, M. N Mazlee and A. G Gibson. (2018). Dynamic Mechanical Analysis and Effects of Moisture on Mechanical Properties of Interwoven Hemp/Polyethylene Terephthalate (PET) Hybrid Composites. Construction and Building Materials, 179 (3), 265-276.

Asim, M.; M. Jawaid, M. T. Paridah, N. Saba, M. Nasir and R. M. Shahroze. (2019), Dynamic and thermomechanical properties of hybridized kenaf/PALF reinforced phenolic composites. Polym. Compos. 40 (3): 3814-3822.

Asim, M.; M. Jawaid, A. Khan, A. M. Asiri and M. A. Malik. (2020). Effects of Date Palm Fibres loading on Mechanical, and Thermal Properties of Date Palm Reinforced Phenolic Composites. Journal of Materials Research and Technology. 9 (3): 3614-3621

Chaudhary, V.; P. K. Bajpai and S. Maheshwari. (2018). An Investigation on Wear and Dynamic Mechanical behavior of Jute/Hemp/Flax Reinforced Composites and Its Hybrids for Tribological Applications. Fibers Polym, 19 (2): 403-415.

Doddi, P. R. V.; R. Chanamala and S. P. Dora (2019). Dynamic mechanical properties of epoxy based PALF/basalt hybrid composite laminates. Materials Research Express. 6 (1), 245-258.

El Messiry M. (2021) Green Composite as an Adequate Material for Automotive Applications. In: Thomas S. and Balakrishnan P. (eds) Green Composites. Materials Horizons: From Nature to Nanomaterials. Springer, pp 151-208

Gupta, M. K. and Singh, R. (2018). Flexural and Dynamic Mechanical Analysis (DMA) of Polylactic Acid (PLA) Coated Sisal Fibre Reinforced Polyester Composite. Materials Today: Proceedings, 5(2), 6109-6114

Gurunathan, T.; S. Mohanty and S. K. Nayak. (2015). A review of the recent developments in biocomposites based on natural fibres and their application perspectives. Composites Part A: Applied Science and Manufacturing, 77 (1), 1-25.

Hamidon, M. H.; M. T. H Sultan, A. H. Ariffin and A. U. M. Shah. (2019). Effects of fibre treatment on mechanical properties of kenaf fibre reinforced composites: a review. Journal of Materials Research and Technology, 65 (1), 154-.169

Horta, J. F.; F. J. Simões, and A. Mateus. (2017). Study of Wood-Plastic Composites with Reused High Density Polyethylene and Wood Sawdust. Procedia Manufacturing,
12, 221-229. International Conference on Sustainable and Intelligent Manufacturing, (RESIM 2016), 14-17, Leiria, Portugal

Hulle, A.; P. V. Kadole and P. A. Katkar. (2015). Agave Americana Leaf Fibers. Fibres. 3 (1) 64-75.

Ijoyah, M. O. and Dzer, D. M. (2012). Yield Performance of Okra (Abelmoschus esculentus L. Moench) and Maize (Zea mays L.) as Affected by Time of Planting Maize in Makurdi, Nigeria. ISRN Agronomy, 3 (1) 1-7.

Isa, M. T.; U. Shehu, B. O. Aderemi, T. K. Bello, H. I. Audu, U. M. Shittu and A. Y. Atta. (2016). Properties of Chemically Modified Baobab Pod/Sisal Fiber reinforced Low Density Polyethylene Hybrid Composite. Nigerian Journal of Material Science and Engineering. 7(1):130-135.

Krishnasamy, P.; G. Rajamurugan and $M$. Thirumurugan. (2019). Dynamic mechanical characteristics of jute Fiber and 304 wire mesh reinforced epoxy composite. Journal of Industrial Textiles, 51 (4): 540-558

La Mantia, F. P and Morreale, M. (2011). Green composites: A brief review. Composites Part A: Applied Science and Manufacturing 42 (5): 579-588.

Letebrhan, K.; K. Marie and D. Hewan. (2020). Comparison and optimization for DNA extraction of okra (Abelmoschus esculentus L. Moench). African Journal of Biotechnology, 19(6): 353-361.

Li, M.; Y. Pu, V. M. Thomas, C. G. Yoo, S. Ozcan, Y. Deng and A. J. Ragauskas. (2020). Recent Advancements of Plant-Based Natural Fiber-Reinforced Composites and Their Applications. Composites Part B: Engineering. 200 (1): $1124-$ 1139.

Mandal, S. and Alam, S. (2012). Dynamic mechanical analysis and morphological studies of glass/bamboo fiber reinforced unsaturated polyester resin-based hybrid composites. Journal of Applied Polymer Science, 125(51), E382-E387

Marcovich, N. E.; M. M. Reboredo and M. I. Aranguren, (1996). Composites from sawdust and unsaturated polyester. Journal of Applied Polymer Science, 61(1): 119-124.

Merzoug, A.; B. Bouhamida, Z. Sereir, A. Bezazi, A. Kilic, A and Z. Candan. (2020). Quasi-static and dynamic mechanical thermal performance of date palm/glass fiber hybrid composites. Journal of Industrial Textiles, 49 (7): 2145-2157.

Misganew M.; D. K. N. Rao, K. R. N. Reddy and M. Avvari. (2020). Dynamic Mechanical Properties of Kenaf, Thespesia Lampas and Okra Fiber Polyester Composites. In: Habtu N.; D. Ayele D, S. Fanta, B. Admasu and M. Bitew. (eds) Advances of Science and Technology. ICAST 2019. Lecture Notes of the Institute for Computer Sciences, Social Informatics and Telecommunications Engineering, 308 (2):1457-1469.

Mohammed, L.; M. N. M. Ansari, G. Pua, M. Jawaid and M. S. Islam. (2015). A Review on Natural Fiber Reinforced Polymer Composite and Its Applications. International Journal of Polymer Science, 2015, 1-15.

Nayak, R.; R. Padhye and L. Arnold. (2017). Meltelectrospinning of nanofibers. Electrospun Nanofibers. 7 (3) $11-40$. 
Negawo, T. A; Y. Polat, F. N. Buyuknalcaci, A. Kilic, N. Saba and M. Jawaid. (2018). Mechanical, Morphological, Structural and Dynamic Mechanical Properties of Alkali Treated Ensete Stem Fibers Reinforced Unsaturated Polyester Composites. Composite Structures. 207, 589-597

Ngbede S.O.; H. N. Ibekwe, S. C. Okpara, U. N. Onyegbule and L. Adejumo. (2017). An Overview of Okra Production, Processing, Marketing, Utilization and Constraints in Ayaragu in Ivo Local Government Area of Ebonyi State, Nigeria. Greener Journal of Agricultural Sciences, 4 (4): 136-143.

Obogai L. E.; Z. Vandi, S. A. Njelle, O. Chukwunwike ans D. I. Obidimma. (2020). Fabrication, Mechanical and Physical Properties of Agba (Prioria Balsamifera) Sawdust Reinforced Polyester composite. International Journal of Applied Science and Engineering review. 3 (1): 7-15.

Odera, R. S.; O. D. Okechukwu, E. M. Ezeh, M. C. Menkitt and P. C Agu. (2021). The exchange of Musa spp. fibre in composite fabrication: a systematic review. Bull Natl Res Cent 45 (1): 1- 8.

Ogunwusi A. A. (2014). Wood Waste Generation in the Forest Industry in Nigeria and Prospects for its Industrial Utilization. Environmental Research, 6 (9): 62-70.

Okonkwo, E. E.; M. O. Ukaegbu and A. P. Eyisi. (2016). A Documentation of Some Traditional Aspects of Wood Consumption in Anaocha, Nigeria. SAGE Open, 6(2): $1-8$.

Oluoti K.; G. Megwai, A. Pettersson and T. Richards. (2014). Nigerian wood waste: A dependable and renewable fuel option for power production. World J.Eng.Tech. 2(3): 234-248.

Owoyemi, J. M.; H. O. Zakariya and I. O. Elegbede. (2016). Sustainable wood waste management in Nigeria. Environmental \& Socio-Economic Studies, 4(3), 1-9.

Paiva, J. M. F and Frollini E. (2006). Unmodified and Modified Surface Sisal Fibers as Reinforcement of Phenolic and Lignophenolic Matrices Composites: Thermal Analyses of Fibers and Composites. Macromol. Mater. Eng. 291, 405417.

Poletto, M. (2017). Mechanical, dynamic mechanical and morphological properties of composites based on recycled polystyrene filled with wood flour wastes. Maderas. Ciencia y Tecnología, 19 (4):433-442.

Popelka, A.; S. Zavahir and S. Habib. (2020). 'Morphology analysis'. In: Al-Maadeed, M.; D. Ponnamma and M. Carignano (eds.) Polymer Science and Innovative Applications, Oxford UK, Elsevier Science, 21-68.

Punyamurthy, R.; D. Sampathkumar, B. Bennehalli, R. P. Ranganagowda, P. V. Badyankal and S. C.
Venkateshappa. (2014). Abaca Fiber Reinforced Hybrid Composites. International Journal of Applied Engineering Research.9 (23): 20273-20286.

Sanjay, M. R.; P. Madhu, M. Jawaid, P. Senthamaraikannan, S. Senthil, and S. Pradeep. (2018). Characterization and properties of natural fibre polymer composites: A comprehensive review. Journal of Cleaner Production, 172, 566-581.

Sethuraman, B.; S. P. Subramani; S. K. Palaniappan, B. Mylsamy and K. Aruchamy. (2020). Experimental investigation on dynamic mechanical and thermal characteristics of Coccinia Indica Fiber reinforced polyester composites. Journal of Engineered Fibers and Fabrics. 15, 16

Siakeng, R.; M. Jawaid, H. Ariffin and S. M. Sapuan. (2018). Physical properties of coir and pineapple leaf fibre reinforced polylactic acid hybrid composites. IOP Conference Series: Materials Science and Engineering, 290 (1): 12-31.

Silva-Guzmán, J. A.; R. R. Anda, F. J. FuentesTalavera, R. Manríquez-González and M. G. LomelíRamírez. (2018). Properties of Thermoplastic Corn Starch Based Green Composites Reinforced with Barley (Hordeum vulgare L.) Straw Particles Obtained by Thermal Compression. Fibers Polym 19 (9): 1970-1979.

Sujaritjuna, W.; P. Uawongsuwan, W. Pivsa-Arta and H. Hamada. (2013). Mechanical property of surface modified natural fiber reinforced PLA biocomposites 10th Eco-Energy and Materials Science and Engineering (EMSES2012) Energy Procedia 34: $664-672$

Thitithanasarn, S.; K. Yamada, U. Ishiaku and $H$ Hamada. (2012). The Effect of Curative Concentration on Thermal and Mechanical Properties of Flexible Epoxy Coated Jute Fabric Reinforced Polyamide 6 Composites. Journal of Composite Mater 2 (4):133-145.

Thyavihalli G. Y.; R. S. Mavinkere, J. Parameswaranpillai and S. Siengchin. (2019). Natural Fibres as Sustainable and Renewable Resource for Development of Eco-Friendly Composites: A Comprehensive Review. Frontiers in Materials, 226 (6):1-8

Unterweger, C.; O. Brüggemann and C. Fürst. (2014). Effects of different fibers on the properties of shortfiber-reinforced polypropylene composites, Composites Science and Technology 103: 49-55.

Valadez-Gonzalez, A.; J. M. Cervantes-Uc, R. Olaya and P. J. Herrera-Franco. (1999). Effect of fiber surface treatment on the fiber-matrix bond strength of natural fiber reinforced composites. Compos Part .30 (3): 309-320.

Zhang, Q.; H. Cai, X. Ren, L. Kong, J. Liu and X. Jiang. (2017). The Dynamic Mechanical Analysis of Highly Filled Rice Husk Biochar/High-Density Polyethylene Composites. Polymers, 9(11): 628-639. 